\title{
Monitoring of Land Surface Temperature \\ in Krasnoyarsk and its Suburban Area Based \\ on Landsat 8 Satellite Data
}

\author{
Aleksandra K. Matuzko and Oleg E. Yakubailik* \\ Institute of Computational Modelling SB RAS \\ 50/44 Akademgorodok, Krasnoyarsk, 660036, Russia
}

Received 27.12.2017, received in revised form 22.04.2018, accepted 09.10.2018

The problem of temperature anomalies is typical for all major cities in the world. Space thermal images are a powerful source of information for analyzing and determining outlines of temperature anomalies within a single territory. Determination of the nature and boundaries of temperature anomalies will help to understand the causes of the unfavorable ecological situation in Krasnoyarsk: where, in addition to high industrial emissions, atmospheric processes also exert their influence, which lead to the fact that impurities linger and concentrate over the city.

The development of advanced space technologies allows the collection of a variety of diverse data more efficiently and at a lower cost than the organization of an appropriate ground network of observation posts and points. One of the most interesting and important indicators about the surface of the Earth is the land surface temperature. Land surface temperature is determined by the balance of incoming and outgoing energy. The main and overwhelming source of energy coming to the surface of the Earth is solar radiation.

The 10th and 11th bands of Landsat 8 satellite measure thermal infrared radiation (TIR). The thermal infrared range is particularly useful for determining the temperature difference between the city and surrounding rural areas, and for studying the phenomenon of an urban heat island (UHI).

Keywords: urban heat island, thermal infrared imagery, Landsat, temperature anomalies, land surface temperature.

Citation: Matuzko A.K., Yakubailik O.E. Monitoring of land surface temperature in Krasnoyarsk and its suburban area based on Landsat 8 satellite data, J. Sib. Fed. Univ. Eng. technol., 2018, 11(8), 934-945. DOI: 10.17516/1999-494X-0115.

(C) Siberian Federal University. All rights reserved

This work is licensed under a Creative Commons Attribution-NonCommercial 4.0 International License (CC BY-NC 4.0).

* Corresponding author E-mail address: akmatuzko@icm.krasn.ru, oleg@icm.krasn.ru 


\title{
Мониторинг температуры земной поверхности \\ в окрестностях Красноярского края \\ на основе данных спутника Landsat 8
}

\author{
А.К. Матузко, О.Э. Якубайлик \\ Институт вычислительного моделирования СО РАН \\ Россия, 660036, Красноярск, Академгородок, 50/44
}

\begin{abstract}
Проблема температурных аномалий характерна для всех крупных городов мира. Космические тепловые снимки являются весомым источником информации для анализа и определения контуров температурных аномалий в пределах одной территории. Определение природы и грании температурных аномалий поможет понять причины неблагоприятной экологической ситуации в Красноярске: где, помимо высоких промышленных выбросов, оказывают влияние атмосферные процессы, которые приводят к тому, что примеси задерживаются и кониентрируются над городом.

Развитие передовых космических технологий позволяет осуществлять сбор множества разнообразных данных более эффективно и с меньшими затратами, чем организация соответствующей наземной сети пунктов и постов наблюдения. Одним из наиболее интересных и важных показателей о поверхности Земли служит температура земной поверхности. Температура на поверхности Земли определяется балансом приходящей и уходящей энергии. Основным и подавляющим источником энергии, поступающей к поверхности Земли, является солнечное излучение.

Каналь 10-й и 11-й Landsat 8 работают в том же диапазоне, что и канал TIR на более ранних спутниках программы Landsat. Каналь 10-й и 11-й спутника Landsat 8 измеряют тепловое инфракрасное излучение или TIR (thermal infrared). Разрешение для тепловых каналов 100 м.
\end{abstract}

Ключевые слова: городской остров тепла, тепловые космические снимки, Landsat, температурные аномалии, температура поверхности Земли

\section{Introduction}

The first images of the Earth from space in the thermal infrared range were received from the American meteorological satellite in 1960. Despite the fact that the data received had a low spatial resolution, the possibility of using thermal remote sensing data for solving a number of meteorological problems was for the first time shown. The article discusses the method of estimating the land surface temperature using Landsat 8 satellite data [1] and evaluates the quality of the received data.

The purpose of the study is to analyze the possibility of applying a technique for monitoring the land surface based on Landsat 8 remote sensing data to determine the temperature anomalies of the land surface in Krasnoyarsk and its suburban area.

The major tasks are:

1. To determine the land surface temperature in Krasnoyarsk and its suburban area for the construction of statistical temperature surfaces. To form the temperature maps of the surroundings of Krasnoyarsk city on the basis of the obtained data.

2. To carry out a comparative analysis of the land surface temperature received from the Landsat 8 satellite data and the air temperature obtained from ground observation stations.

$$
-935-
$$


Landsat 8 satellite acquires data using two different sensors - Operational Land Imager (OLI) and Thermal Infrared Sensor (TIRS). These devices collect data in nine short-wave ranges and two longwave thermal ranges. Thus, Landsat 8 images consist of 11 spectral ranges, where the 10th and 11th bands are long-wavelength infrared (thermal infrared), which allows them to analyze the energy of the land surface rather than the reflection of sunlight.

\section{Analysis of recent research and publications}

The collection of space imagery materials in the thermal infrared range has been accumulating since the 1960s, however, images of this range are much less used to study natural and anthropogenic objects and processes than images of other spectral ranges.

The satellites of the National Oceanic and Atmospheric Administration (NOAA) of the United States have operated since 1970, the main sensor of NOAA is AVHRR, which measures the reflectivity of the Earth in 5 relatively wide spectral bands $(0.6 \mu \mathrm{m}, 0.9 \mu \mathrm{m}, 3.5 \mu \mathrm{m}, 11$ and $12 \mu \mathrm{m})$. Currently, the AVHRR device captures images with a spatial resolution of $1.1 \mathrm{~km}$ in the $2500 \mathrm{~km}$ survey band, making up a complete image of the Earth's surface in one day. The main purpose of the tools is to monitor the cloud cover and measure the outgoing heat radiation of the Earth. The sensor captures data from which the surface temperatures of the ocean and land are determined. The AVHRR data archive spans more than 40 years, and is of great importance in studying climate and environmental changes $[2]$.

The MODIS (Moderate Resolution Imaging Spectroradiometer) spectroradiometer is one of the key instruments on board the US satellites Terra and Aqua, it captures 36 channels: 12 of them in the visible range, 8 in the near and middle infrared bands, and 16 in the thermal infrared range. Two channels have a spatial resolution of $250 \mathrm{~m}$, five channels $-500 \mathrm{~m}$, and 29 channels (including all thermal infrared) are characterized by a spatial resolution of $1000 \mathrm{~m}$. The width of the shooting strip is $2300 \mathrm{~km}$. The widespread use of MODIS data is primarily due to the main advantages of the system: a relatively high time resolution, a large number of bands. Due to its peculiarities, MODIS data provides the solution of various tasks for regular monitoring of natural phenomena at a large regional level. The coverage of geosystems that allow to study these images is the same as that of AVHRR, however, the spectral resolution of the MODIS system is much higher, which allows revealing subtle differences between the geosystems studied [3].

The American program Landsat began its existence in 1972, since then seven satellites were launched. The collected archive of images allows analyzing the changes that have occurred on Earth for more than 40 years. The Landsat 3 satellite used the MSS (Multispectral Scanner) imaging system, which received images with a spatial resolution of $80 \mathrm{~m}$ in the visible and near infrared ranges and $240 \mathrm{~m}$ in thermal infrared. The Landsat 4 and Landsat 5 satellites were equipped with two types of scanners that provided a survey of the Earth's surface with different spatial and spectral resolution - the MSS and TM (Thematic Mapper, a spatial resolution of $30 \mathrm{~m}$ in the visible, near and middle infrared zones, $120 \mathrm{~m}$ in the thermal range). The Landsat 7 satellite is in orbit since April 15, 1999. The ETM+ radiometer installed on the satellite is an improved version of the TM scanners. The main difference of this device is the presence of a high-resolution panchromatic channel $(15 \mathrm{~m})$ and an increase of spatial resolution in the thermal channel to $60 \mathrm{~m}$. Since the end of May 2003, due to the failure of one of the elements of the survey system, the ETM+ radiometer is not working correctly, The operation of the 
equipment led to a decrease in the quality of the data. The launch of the new Landsat 8 satellite (the Landsat Data Continuity Mission project) took place in February 2013, the Thermal InfraRed Sensor (TIRS) scanner was created in the NASA Goddard Space Flight Center and is intended for imaging in the long-wavelength infrared. Quantum Well Infrared Photodetectors (QWIP) based on GaAs [4] are installed in the TIRS's focal plane. The TIRS tool uses the same push broom principle of receiving images as the OLI, and also has a viewing band of 185 kilometers. Bands 10th and 11th Landsat 8 operate in the same range as the TIR channel on earlier Landsat satellites. The bands of the 10th and 11th Landsat 8 satellite measure thermal infrared (IR) radiation or TIR (thermal infrared). The resolution for thermal channels is $100 \mathrm{~m}$. It should be noted the most important fact that the images of the ETM+ system have the highest spatial resolution among the thermal space images available in the open access at $60 \mathrm{~m}$. Spatial resolution of images in the thermal channel of the TM system is equal to $120 \mathrm{~m}$, and for TIRS system it's equal to $100 \mathrm{~m}$. The temporal resolution of images of TM, ETM+ and TIRS systems is equal to 16 days ( 8 days in the overlapping area of the orbits). These parameters allow study of regional geosystems [5].

ASTER (Advanced Spaceborne Thermal Emission and Reflection Radiometer) is installed on the Terra spacecraft, which was launched in December 1999. ASTER is a multi-channel high-resolution sensor that allows remote sensing both in the visible and in the thermal infrared range. The ASTER program was introduced for a more detailed and in-depth study of phenomena on the Earth's surface and in the Earth's atmosphere as part of the US EOS (Earth Observing System) program. The radiometer receives data in 14 spectral ranges: 3 in the visible and near infrared spectral regions, 6 in the middle infrared and 5 in the thermal spectrum, with spatial resolution of 15,30 and 90 meters respectively, and a $60 \times 60 \mathrm{~km}$ frame size on the terrain. The data of the middle infrared range stopped coming in early 2008 due to overheating of the sensors of this range $[6,7]$.

The most common application of thermal space imagery in science is the exploration of globallevel geosystems based on low spatial resolution imagery. The prevailing approach from the point of view of processing techniques is to extract temperatures of the terrestrial and water surfaces from the thermal space images and to analyze their distribution on the Earth. Therefore, the solution of problems at the regional level deserves special attention of the researcher.

\section{Data and Methodology}

The land surface temperature is one of the main parameters in the physics of processes on the Earth's surface, which characterizes the interaction between the atmosphere and the surface. Knowledge of the land surface temperature is required for a variety of scientific studies, including climatology, hydrology and ecology. In particular, the temperature data is necessary for solving problems such as assessment of soil moisture, detection and forecast of frosts, monitoring of the state of cereal crops. The land surface temperature is also one of the indicators of the greenhouse effect and anthropogenic impact on natural resources [8]. Regular temperature monitoring allows us to analyze time series of the global surface temperature and to estimate its variability within different periods.

Satellite remote sensing is the only resource of obtaining long-term homogeneous series of temperature data of regional and global coverage. For remote temperature determination, measurements of outgoing heat radiation in the range of $10.5-12.5 \mu \mathrm{m}$ using the scanning radiometers installed on Earth remote sensing satellites for the last 30 years have been used. The need to obtain regular 
satellite data on the land surface temperature is dictated by the fact that the network of ground-based observations is quite sparse.

The creation of methods for the rapid acquisition of temperature from the data of new geostationary satellites makes it possible to ensure the regular creation of temperature maps for large areas. Such data can significantly supplement the observations of a sparse terrestrial observational network, which is especially important for sparsely populated regions of Russia [9].

From the values of the thermal channels data, it is possible to determine the radio brightness temperature of the underlying surface. Instead of measuring air temperature, as weather stations do, satellite systems measure the surface temperature, which is often higher. Theoretically, the accuracy of the temperature estimation is about $0.5^{\circ} \mathrm{C}$, however, atmospheric haze can reduce the values by several degrees. The initial data for determining the temperature are the values of the intensity of the radiation coming to the sensor of the satellite and registered by the corresponding thermal channel. Based on the values of these heat channels, we calculate the value of the land surface temperature using the formula [1]:

$$
T=\frac{T_{B}}{1+\left(\lambda \frac{T_{B}}{c_{2}}\right) \ln (\mathrm{e})},
$$

$\lambda=$ wavelength of emitted radiance; $c 2=h^{*} c / s=1.4388 * 10-2 \mathrm{c} 2=\mathrm{h} * \mathrm{c} / \mathrm{s}=1.4388 * 10-2 \mathrm{~m} \mathrm{~K}=14388 \mu \mathrm{m} \mathrm{K}$; $h=$ Planck's constant $=6.626 * 10-346.626 * 10-34 \mathrm{~J} \mathrm{~s} ; s=$ Boltzmann constant $=1.38 * 10-231.38 * 10-23 \mathrm{~J} / \mathrm{K}$; $c=$ velocity of light $=2.998 * 1082.998 * 108 \mathrm{~m} / \mathrm{s} ; \mathrm{e}-$ the emissivity; $\mathrm{T}_{\mathrm{B}}-$ the At-Satellite Brightness Temperature $(\mathrm{K})$.

The values of the coefficients the emissivity are presented in the table, and they depend on the type of the Earth's surface (the values used are approximate, since the radiation coefficient of each material must be obtained from the field survey) (Table 1).

The wavelength values for the 10th and 11th Landsat channels are shown in Table 2. Since January 6,2014 , USGS recommended not using the data of the 11th channel band due to the large uncertainty of

Table 1. Correspondence of the Earth's surface and the value of the emissivity

\begin{tabular}{|c|c|}
\hline Land surface & Emissivity \\
\hline Water & 0.98 \\
\hline Built-up & 0.94 \\
\hline Vegetation & 0.98 \\
\hline Bare soil & 0.93 \\
\hline
\end{tabular}

Table 2. The values of $\lambda$ for the bands 10 th and 11 th Landsat 8

\begin{tabular}{|c|c|}
\hline Band & Value $\lambda(\mu \mathrm{m})$ \\
\hline Landsat 8 band 10th & 10.8 \\
\hline Landsat 8 band 11th & 12 \\
\hline
\end{tabular}


the calibration, and 10th band is used to calculate land surface temperature. The resulting temperature should be converted to Celsius degrees.

The thermal infrared range is particularly useful for determining the temperature difference between a city and the surrounding rural areas, and for studying the phenomenon of an urban heat island. The initial data for determining the land surface temperature is the archive of Landsat 8 satellite images. Software: QGIS 2.18.1 with the Semi-Automatic Classification Plugin (SACP) plug-in [9].

One of the most important stages of preliminary processing of space images is the atmospheric correction. The geodata on all Landsat 8 channels are provided as Levell processing level data products, radiometrically calibrated and with systematic geometric corrections applied using the spacecraft ephemeris data. It is necessary to perform additional manipulation with data to obtain desired value. The data should be converted into radiation indices on the sensor, and the atmospheric correction should be performed. After preliminary processing, we form a virtual raster from the loaded layers to determine the type of the Earth's surface and perform the further classification of the image. Let's create a virtual raster from layers 4,3,2 (near infrared, red and green) to display space image as 'false color' composite which is similar to traditional color infrared aerial photography and is widely used in vegetation studies.

On the virtual raster, it is necessary to get graphic samples (Regions Of Interest - ROI) for semiautomatic classification. Select the image of the water surface on the image, and create a polygon corresponding to the macro "Water", and create several polygons in different parts of the image that way. We also do the same for each of the classes: water, buildings, grass / vegetation, open soil. After creating several ROIs for each class of the Earth's surface, we can perform a classification of the entire image. Then we set the natural colors for each macro-class, thus, for example, the water class is colored blue and the vegetation class is green.

The maximum likelihood classification algorithm is best suited for solving our problem. The classified raster is reclassified according to the class of the Earth's surface (Table 1). In the resulting raster, each pixel of the raster image takes the value of the emission factor.

Table 3. Comparison of data obtained on AWS and on the satellite images

\begin{tabular}{|c|c|c|c|c|c|c|}
\hline \multirow{2}{*}{ Date } & \multicolumn{3}{|c|}{ AWS data in 12 hours, ${ }^{\circ} \mathrm{C}$} & \multicolumn{2}{c|}{ Temperature on the satellite images, ${ }^{\circ} \mathrm{C}$} \\
\cline { 2 - 7 } & $\begin{array}{c}\text { Dudinskaya } \\
\text { station }\end{array}$ & $\begin{array}{c}\text { Minusinskaya } \\
\text { station }\end{array}$ & $\begin{array}{c}\text { Roev Ruchey } \\
\text { station }\end{array}$ & $\begin{array}{c}\text { Dudinskaya } \\
\text { station }\end{array}$ & $\begin{array}{c}\text { Minusinskaya } \\
\text { station }\end{array}$ & $\begin{array}{c}\text { Roev Ruchey } \\
\text { station }\end{array}$ \\
\hline 07.10 .2016 & 5,4 & 3 & 0,4 & 7 & 3 & 2 \\
\hline 05.09 .2016 & 16,3 & 15 & 17,6 & 22 & 19 & 19 \\
\hline 10.06 .2016 & 25 & 23,4 & 26,1 & 33 & 25 & 28 \\
\hline 23.04 .2016 & 15,1 & 12,2 & 15,4 & 22 & 19 & 18 \\
\hline 17.07 .2015 & 24,6 & 23 & 26 & 34 & 24 & 29 \\
\hline 01.07 .2015 & 30,4 & 28 & 30,9 & 34 & 29 & 29 \\
\hline 08.06 .2015 & 24 & 22,6 & 24,9 & 30 & 25 & 27 \\
\hline 14.05 .2015 & 19,8 & 18,5 & 21,7 & 25 & 24 & 27 \\
\hline 07.07 .2014 & 29,1 & 27,3 & 30,3 & 32 & 27 & 31 \\
\hline 18.06 .2013 & 29,9 & 27 & 21,1 & 33 & 34 & 21 \\
\hline
\end{tabular}




\section{Results}

The land surface temperature is calculated by the formula (1). We translate the obtained temperature values to Celsius degrees using the Band calc calculator, and compile land surface temperature map of the in Krasnoyarsk and its suburban area on the basis of obtained values (Fig. 1).

The image shows that the temperature of the river is much lower than the surface temperature of urban areas, although in a natural environment in spring the temperature of the water in the river is usually higher than the air temperature. The construction of a hydroelectric power plant on the Yenisei River, twenty-seven kilometers upstream from Krasnoyarsk, near the city of Divnogorsk, had a great influence on the distribution of seasonal temperatures in the city [10].

Changes in the thermal regime of the river as a result of hydraulic engineering construction in comparison with natural conditions affect the work not only of the hydroelectric complex itself, but also of water management facilities, water transport, and also water quality and climate. For the downstream of hydroelectric power stations, regardless of the period of the annual cycle, characteristic changes in the water temperature take place along the length of the downstream. In the non-freezing period, it changes from the temperature of the water entering the downstream from the upstream (reservoir) to a steady temperature corresponding to the heat exchange of the stream with the atmosphere. In winter, along the length of the downstream water is cooled to $0^{\circ} \mathrm{C}$. In the spring-summer period, the water in the lower tunnels is colder than in natural conditions due to the slower heating of the water masses of the reservoirs. Thus, the temperature of the Yenisei water in Krasnoyarsk and its suburban area in the summer is $8-10{ }^{\circ} \mathrm{C}$ lower than before the regulation of the river, and, conversely, is increased by $4-5{ }^{\circ} \mathrm{C}$ in the autumn months, which created certain difficulties in the development of the adjacent territory and had a significant impact on the climate of Krasnoyarsk city [11].

Let's compare the results obtained by our method with the data obtained from ground automatic weather stations (AWS). As described above, 10 satellite images received in the summer-autumn period over the time interval from 2013 to 2016 were processed. Based on the data, on satellite images and

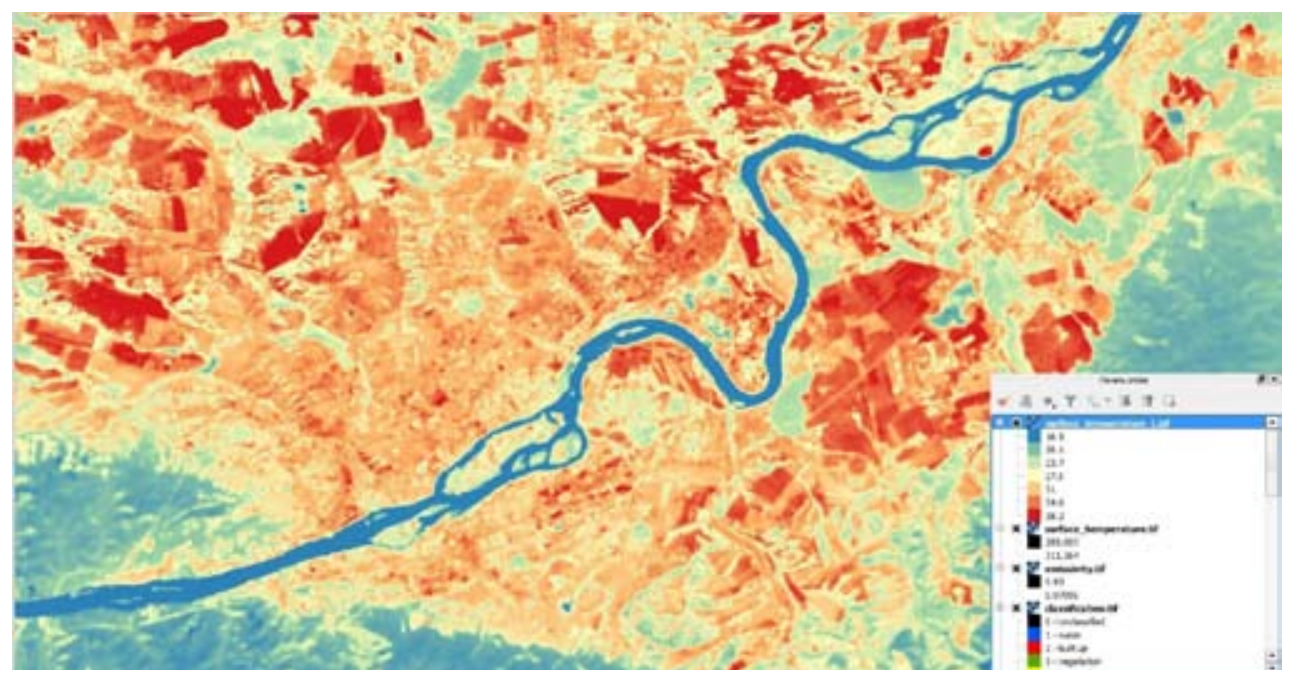

Fig. 1. Surface Temperature of the Krasnoyarsk city 
from the AWS, we will compile a summary table for the three control points in the city, for AWS on Dudinskaya str., Minusinskaya str. and at Roev Ruchey str. [12].

We will compile diagrams for each of the investigated territories separately using the data presented in the table. The diagrams show that the temperature obtained on the basis of space images is insignificantly higher than the values that were obtained on the AWS (Fig. 2).

To cut off artifacts on the surface of the earth, which can locally affect the results of calculations we average the values of the obtained temperature values to $100 \times 100$ meters. Having obtained the temperature map of Krasnoyarsk, the warmest regions in the city are visible on Fig. 3. Compare the location of these sites for the ten images discussed earlier.

To find the maximum temperature values within the city, all the pictures were grouped by the seasons: summer, spring and autumn. To track the time dynamics, let's look at summer images (Fig. 4).

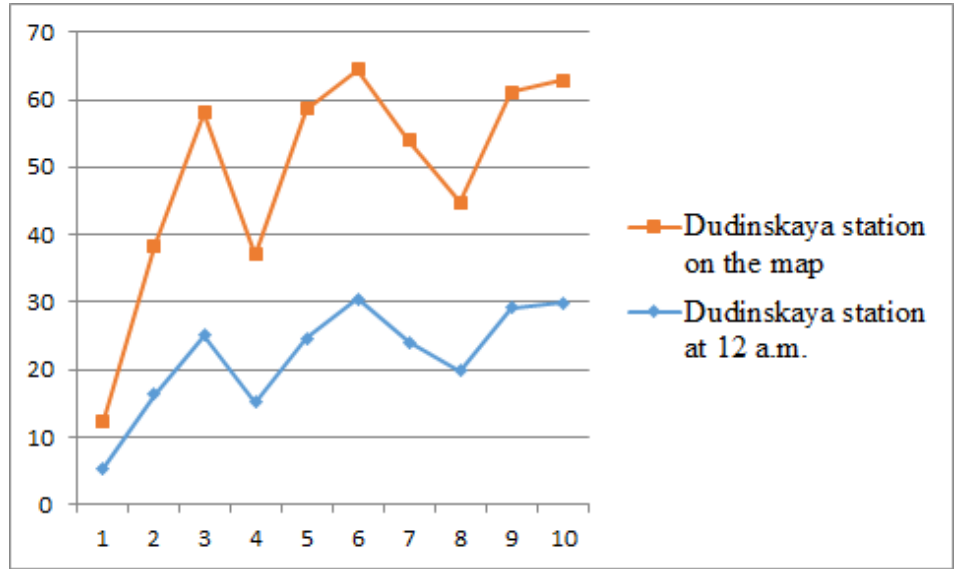

Fig. 2. Temperature comparison charts for AWS and remote sensing

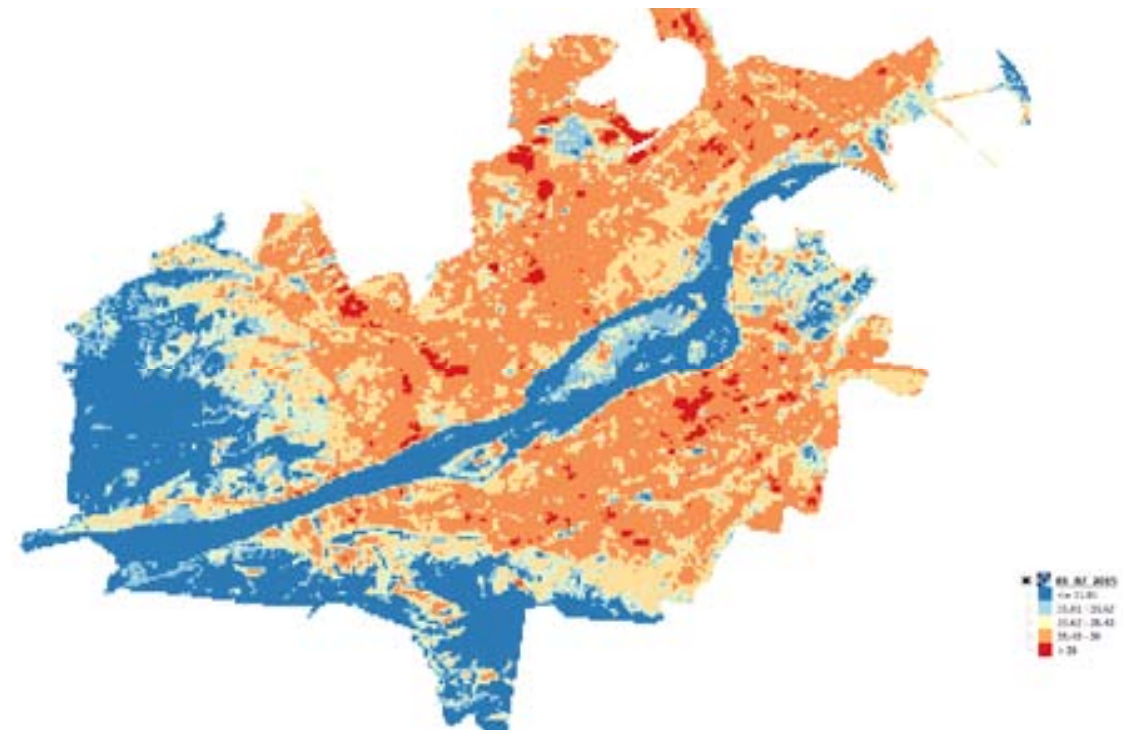

Fig. 3. Surface Temperature of the Krasnoyarsk city 


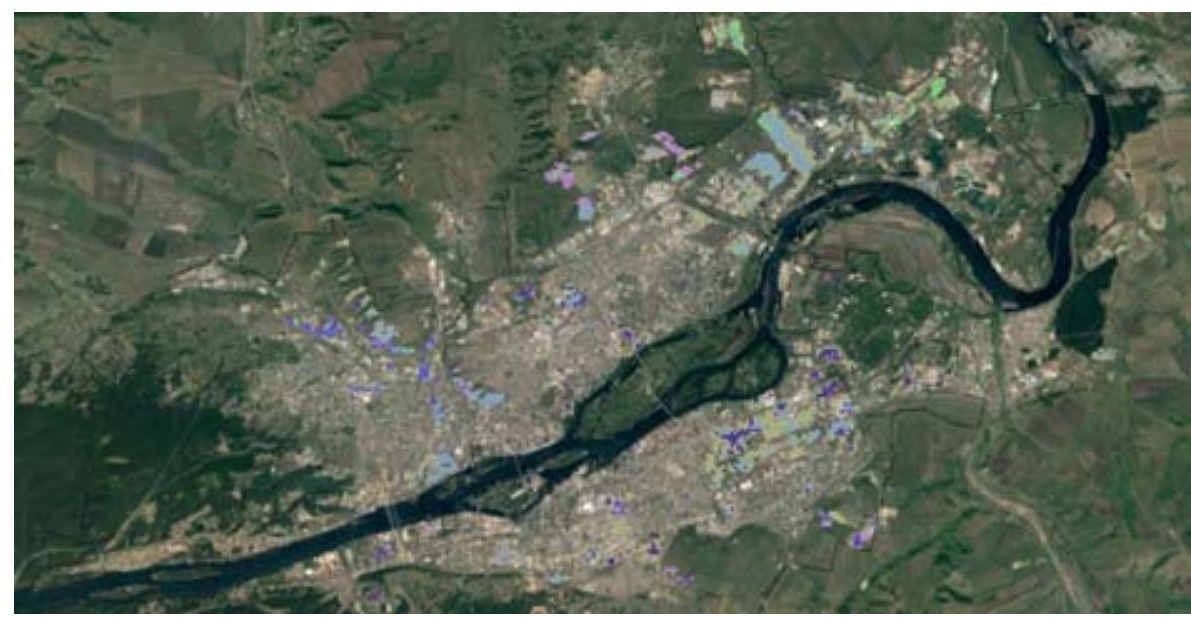

Fig. 4. Distribution of maximum temperature values in summer

\section{The discussion of the results}

Based on the results of the analysis of summer thermal multi-temporal space images, several thermal zones of different nature were outlined on the territory of the city of Krasnoyarsk. On summer photographs, such zones as natural elevations, shopping centers, industrial zone have the maximum surface temperature.

The fragments of the map show the distribution of maximum temperatures from the analysis of seven space images of Landsat 8. Thus, in the Zheleznodorozhny district of Krasnoyarsk, the Pokrovskaya Gora has the highest surface temperature, due to the open grassy slopes and thin cover of the landscape. Also in summer, the railway station has the maximum temperature of the surface and a significant excess of surface temperature (Fig. 5).

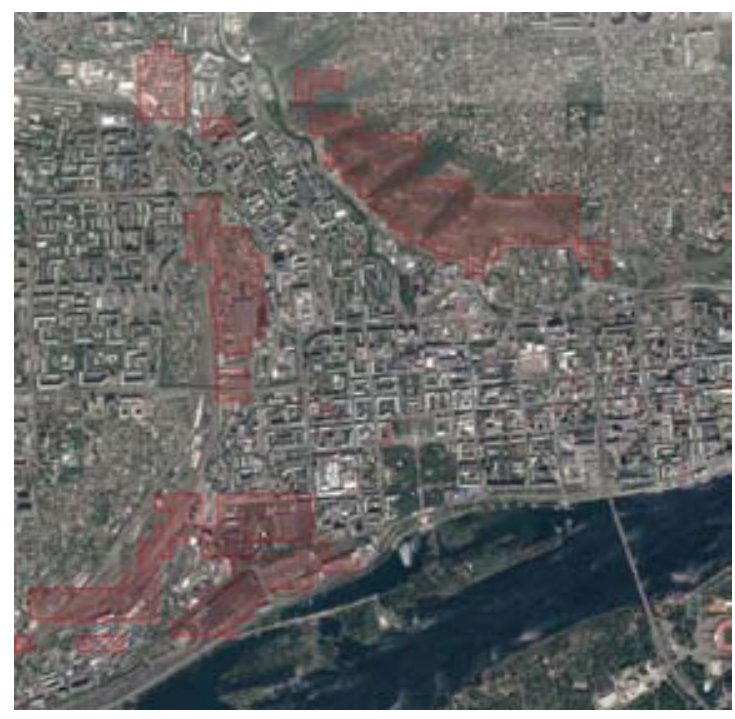

Fig. 5. Railway station Krasnoyarsk 


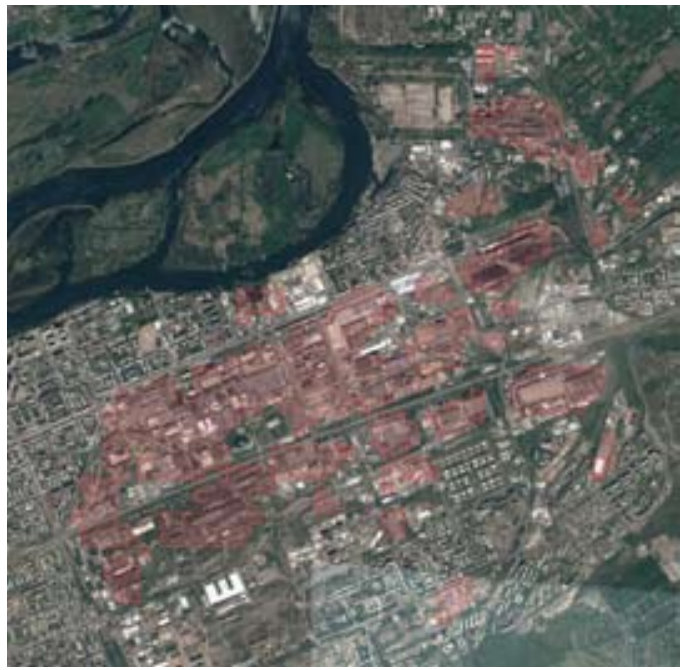

Fig. 6. Industrial zone, right bank of the city of Krasnoyarsk

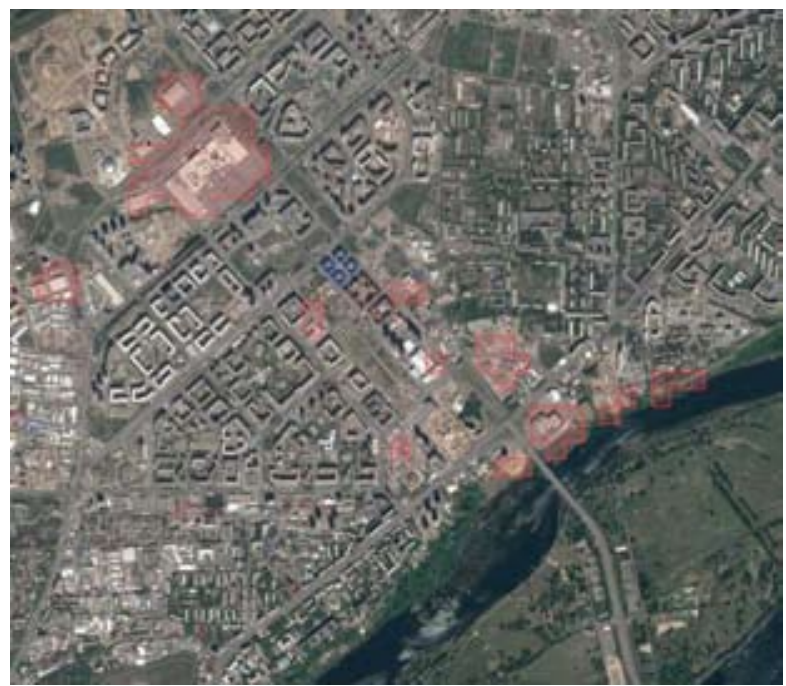

Fig. 7. Sovetskiy district of the city of Krasnoyarsk

Figure 6 shows that the highest temperatures observed in the collection of summer photographs are on the right bank of Krasnoyarsk, where the industrial zone of the city prevails.

In the Sovietsky district of the city, located on the left bank, the maximum temperatures also prevail in the industrial zone of the city, but also in the places of the concentration of shopping and entertainment centers. Figure 7 shows that the form of heat spots corresponds to the form of shopping centers: TRC Planeta, Lenta, June, Motor shows, Aviator, TC Commander.

\section{Conclusions}

The article presents a technique for monitoring the land surface temperature on the basis of the thermal infrared data from the 10th band of Landsat 8 satellite. Analysis of ten satellite images of 
Landsat 8 made at different times of the year from 2013 to 2016 was carried out. A comparison was made between the data calculated on the basis of satellite images and the air temperature recorded on the AWS.

The difference between the air temperature by AWS and the land surface temperature, calculated on the basis of satellite data, can reach several degrees. It should be noted that sometimes the difference between the land surface temperature and the AWS can be sharp, since we compare two different temperatures in different places (AWS is between 1.1 and $2.0 \mathrm{~m}$ from the ground). But despite the difference in measurements, this technique opens up unlimited opportunities for researchers to explore areas that are not equipped with AWS, but are in the coverage area of Landsat 8.

The analysis of temperature maps made it possible to reveal the temperature anomalies characteristic of the Krasnoyarsk city territory. The results section lists the zones where the surface temperature is raised by several degrees relative to neighboring surfaces.

\section{References}

[1] Niclos R., Valiente J.A., Barbera M.J., Caselles V. Land Surface Air Temperature Retrieval from EOS-MODIS Images, IEEE Geoscience and Remote Sensing Letters. 2014, 11(8), $1380-1384$.

[2] Stathopoulou M., Cartalis C. Downscaling AVHRR land surface temperatures for improved surface urban heat island intensity estimation, Remote Sensing of Environment. 2009, 113, 2592 2605.

[3] Merlin O., Duchemin B., Hagolle O., Jacob F., Coudert B., Chehbouni G., Dedieu G., Garatuza J., Kerr Y. Disaggregation of MODIS surface temperature over an agricultural area using a time series of Formosat-2 images. Remote Sens. Environ. 2010, 114, 2500-2512.

[4] Лурье И.К., Косиков А.Г. Теория и практика цифровой обработки изображений, Научный мир. 2003, 166 [Lurie I.K., Kosikov A.G. Theory and practice digital processing images, Nauchniy mir. 2003, 166. ISBN 5-89176-231-5 (in Russian)]

[5] Weng Q., Lu D. \& Schubring J. Estimation of land surface temperature-vegetation abundance relationship for urban heat island studies, Remote Sensing of Environment, Elsevier Science Inc.. Box 882 New York NY 10159 USA, 2004, 89, 467-483.

[6] Frey C.M., Parlow E. Flux measurements in Cairo. Part 2: On the determination of the spatial radiation and energy balance using aster satellite data. Remote Sens. 2012, 4, 2635-2660.

[7] Lu D., Weng Q. Spectral mixture analysis of ASTER images for examining the relationship between urban thermal features and biophysical descriptors in Indianapolis, Remote Sensing of Environment. USA, 2006, 104, 157-167.

[8] Асмус В.В., Дядюченко В.Н., Загребаев В.А. и др. Наземный комплекс приема, обработки, архивации и распространения спутниковой информации, Тр. НИЦ «Планета». 2005, 1(46), 3-21. [Asmus V.V., Dyadychenko V.N., Zagrebaev V.A. and others. Surface complex for receiving, processing, archiving and distribution of satellite data, SIC "Planeta" works. 2005, 1(46), 3-21. (in Russian)]

[9] Congedo L. Semi-Automatic Classification Plugin Documentation [Electronic resourse] - Access: http://www.fromgistors.blogspot.com/ 
[10] Hrebtov M., Hanjalić K. Numerical study of winter diurnal convection over the city of Krasnoyarsk: Effects of non-freezing river, undulating fog and steam devils, Boundary Layer Meteorology. 2017, 469-495.

[11] Матузко А.К. Определение температуры поверхности воды по данным дистанционного зондирования земли, Региональные проблемы дистанционного зондирования Земли:материаль IV Междунар. науч. конф. Красноярск: СФУ, 2017, 271-274 [Matuzko A.K. Determining water surface temperature by Earth remote sensing data, Regional problems of Earth remote sensing, Materials of IV International Scientific Conference. Krasnoyarsk: SFU ISIT, 2017, 271-274. (in Russian)]

[12] Матузко А.К. Методика определения температуры земной поверхности на основе данных дистанционного зондирования, Конференция молодых ученых ИВМ СО РАН по математическому моделированию и информачионным технологиям: материалы открытой конференции молодых ученых ИВМ СО РАН по математическому моделированию и информационным технологиям. Красноярск, 2017, 21-24 [Matuzko A.K. Methodology of determining earth surface temperature based on remote sensing data, Open conference of ICM SB RAS young scientists on mathematical modelling and information technologies, conference materials. Krasnoyarsk: ICM SB RAS, 2017, 21-24 (in Russian)] 